\title{
Is lachrymal fluid a potential method for cortisol measurement in wild harbor seals? A pilot study
}

\author{
Neele Hendrika Gundlach ${ }^{1}$, Marion Piechotta $^{2}$ and \\ Ursula Siebert ${ }^{3}$ \\ ${ }^{1,3}$ Institute for Terrestrial and Aquatic Wildlife \\ ${ }^{1,2,3}$ Research and Clinic for Cattle, Endocrinology Laboratory, University of Veterinary Medicine \\ Hannover, Foundation, Buesum, Germany \\ Correspondence should be addressed to: Ursula Siebert; ursula.siebert@tiho-hannover.de
}

Received date: 10 January 2014; Accepted date: 14 March 2014;

Published date: 16 September 2016

Academic Editor: Rony Geers

Copyright (C) 2016. Neele Hendrika Gundlach, Marion Piechotta and Ursula Siebert. Distributed under Creative Commons CC-BY 4.0

\begin{abstract}
Despite stable population size in harbor seals anthropogenic interferences in the marine environment still represent a highly discussed matter within research. In order to quantify and evaluate assumed stressful events in the marine environment, there is a permanent search for new methods and materials for the evaluation of stress. Previous studies are often based on venipuncture and determination of the classic "stress-related hormones" in blood, showing the change of activity of the hypothalamic pituitary adrenocortical (HPA) axis as well as the sympathetic adrenomedullary system. Though blood sampling represents the gold-standard, it is influenced by disturbance of sampling, representing an invasive stressful method itself. Therefore, new non-invasive approaches have to be developed to determine HPA modifications as well as other matrices to reduce stress caused by handling and trapping. In addition to saliva and blood, the present study tested cortisol measurement in lachrymal fluid as a possible method for rapid stress evaluation. Therefore, 17 harbor seals (13 male, four female) were examined during a health monitoring program in April 2013. Lachrymal fluid was collected using a swab which was carefully inserted into the conjunctival sack. For comparison, serum and saliva were also sampled afterwards. Cortisol was detected in lachrymal fluid, saliva and blood of all investigated animals. Evaluation of regression analysis showed a good correlation $\left(\mathrm{R}^{2}=0.82\right)$ between serum cortisol and "free" cortisol in lachrymal fluid. This study showed for the first time the possibility of lachrymal fluid sampling as a non-invasive method to asses stress in harbor seals.
\end{abstract}

Keywords: cortisol, harbor seal, lachrymal fluid

Cite this Article as: Neele Hendrika Gundlach, Marion Piechotta and Ursula Siebert (2016), " Is lachrymal fluid a potential method for cortisol measurement in wild harbor seals? A pilot study ", International Inurnal nf Veterinary Medicine. Recearch \&, Renorte Vol J016rJn16) Article In 967042 


\section{Introduction}

After two seal epizootics caused by phocine distemper virus (Haerkoenen et al., 2006), harbor seal population size has reached a maximum in the Wadden Sea $(39.400$ estimated harbor seals) since counting has started (Trilateral Seal Expert Group (TSEG) 2013). In spite of this development, harbor seals are exposed to a large number of anthropogenic activities in the marine environment including noise, pollution by offshore wind farms, ship traffic, fisheries, military activities and chemical pollution (Fair 2000, review Siebert et al., 2012, Mueller 2013). Such "environmental stress", concerns every change in the environment (stressor) of an individual. It can challenge the normal capacity of reaction and therefore demands a certain effort of adaptation (Swietlik 2011, Evans 1984). Adaptation describes the ability to cope with changes, here environmental demands and circumstances. Thus, adaptation can lead to an alteration of behaviour, metabolism and also hormonal status. However, for example in accordance with Koolhaas et al., (2011) a prolonged exposure to a stressor might also exceed the adaptive capacity. This may result in a phase of exhaustion combined with possible pathological consequences.

Hence, in order to quantify and evaluate assumed stressful events in the marine environment there is continuous research for new approaches, methods and materials to evaluate acute and chronic stress. Previous studies are often based on blood collection by venipuncture and determination of "stress-related hormones", investigating the activation of the hypothalamic pituitary adrenocortical (HPA) axis as well as the sympathetic adrenomedullary system. Though blood sampling is described as a gold-standard, it is influenced by intensive handling and fixation of wild animals (Cook et al., 2000, Moestl et al., 2002). Consequently, there is a need of new advances to determine HPA modifications.

Lachrymal fluid has already been utilized for stress research in different species, for example in humans (Banbury 2009) and cattle (Khraim 2011). Tears are secreted by different ocular glands to hydrate and lubricate the surface in order to provide optimal conditions and prevent eye damage. It consists of sodium chloride, glucose and proteins as well as enzymes like lysozyme and lipocalin and steroid hormones like cortisol (Banbury 2009). Sampling of tear fluid like saliva has the advantage of presenting a non-invasive method to investigate body fluids in different ways. Previous projects discovered that there is a smaller risk of potential contamination with blood or other ingredients in contrast to saliva in the oral cavity (Banbury 2009).

Compared to blood, tear fluid and saliva are devoid of binding proteins. Here the analysis is based on the unbound endogenous form of cortisol.

The aim of the present pilot study is to identify the potential of lachrymal fluid as a non-invasive, quick and potentially reliable sampling method for cortisol measurement in wild harbor seals.

\section{Research design and methodology}

Harbor seals (Phoca vitulina, $n=17 ; 13$ males, four females) were examined during a health monitoring program in April 2013 under the direction of the assigned Institute for Terrestrial and Aquatic Wildlife Research (ITAW) of the University of Veterinary Medicine Hannover Foundation (medical monitoring permit number for animal experiments/sampling V312-72241.121-19; Ministry of Energy, Agriculture, the Environment and Rural Areas Schleswig-Holstein, Germany). The procedure is described by Hasselmeier et al., (2008). The examination consisted of a determination of weight, length, sex, blubber thickness and external examination. According to Hasselmeier et al., (2008) three age groups were classified: 1. animals born the same year of the catch (pups), 2. seals born the previous year (yearlings, immature), 3. animals at least two years old (older, mature). Furthermore, the following materials were sampled from each animal in the following order: lachrymal fluid, saliva and blood. All 
samples were stored in a cool bag until further processing.

\section{Blood sampling}

Blood was obtained from the extradural intravertebral vein as described by Hasselmeier et al., (2008).

\section{Saliva and lachrymal fluid sampling}

A swab (Salivette $®$, Sarstedt AG \& Co., Nuembrecht, Germany) was inserted in the buccal cavity for about 30 seconds to collect saliva.

For lachrymal fluid sampling, a cotton swab (Henry Schein VET GmbH, Hamburg, Germany) was used which was carefully inserted into the conjunctival sack for 15 seconds, trying to avoid the stimulation of lacrimation. Samples were kept cool on ice afterwards. The swabs as well as the serum and saliva samples were stored in aliquots at $-20^{\circ} \mathrm{C}$ until analysis.

\section{Laboratory analysis}

\section{Blood counts and clinical chemistry}

Investigations of the distribution of blood cells (Vet abc, scil, Viernheim, Germany) as well as clinical chemistry (VetScan $\AA$, Abaxis Inc., Union City, CA, USA) were performed using commercial analyzer for veterinarian purpose with impedance measurement in accordance to Hasselmeier et al., (2008).

\section{Serum}

For the determination of cortisol in blood a chemiluminescence immunoassay was used (Immulite 1000 systems, Siemens Healthcare Diagnostics GmbH, Eschborn, Germany). Analysis was performed according to instructions of the manufacturer. The analytical sensitivity was $2 \mathrm{ng} / \mathrm{ml}$. The intra-assay coefficient of variation (CV) was $4.5 \%$ and inter-assay imprecision was $8.8 \%$. There is an observed crossreactivity of approximately $49 \%$ with prednisolone, $21 \%$ with methylprednisolone, $\quad 8.6 \% \quad$ with corticosterone, $5.9 \%$ with prednisone and $0.2 \%$ with fludocortisone.

\section{Saliva and lachrymal fluid}

The cortisol concentration in saliva and lachrymal fluid was analyzed using a commercial cortisol ELISA (Cortisol free in Saliva ELISA DES6611; Demeditec Diagnostics GmbH, Kiel, Germany) for quantitative determination of the free, unbound form of cortisol in saliva and tears. The intra-assay coefficients of variations for the two types of samples were as followed: 5.6 and $4.7 \%$. The linearity of dilution was determined by diluting one sample of a seal in 10 dilution steps (geometrical dilution) herewith a nearly linear dilution was achieved. From this dilution the lower detection limit was determined and adjusted to $0.125 \mathrm{ng} / \mathrm{ml}$.

Before determining cortisol in saliva and lachrymal fluid, samples had to be pretreated for cortisol extraction as follows. Swabs were removed from its transport tube and transferred into a Falcon tube. The extraction of cortisol was done by adding $3 \mathrm{ml}$ ether mixture to the swabs, whose linearity was saturated with saliva and lachrymal fluid for a standardized time period of 30 seconds. For one hour, the swabs were incubated with ether at room temperature on an orbital shaker. Afterwards, the processed samples were stored at $-80^{\circ} \mathrm{C}$ over night to freeze the liquid layer. The tubes were put in a vacuum centrifuge for 45 minutes and $120 \mu \mathrm{l}$ of the ELISA standard was added to the tubes and mixed thoroughly. Samples were stored at $-20^{\circ} \mathrm{C}$ until analysis.

Before further processing, samples were thawed at room temperature and centrifuged at $1000 \mathrm{~g}$ for 5 minutes in order to remove possible impurities.

ELISA was carried out in accordance to the manufacturer's instructions. The data was evaluated using the program Magellan Software in cubic spline modus (Magellan Software GmbH, Dortmund, Germany). Cross reactivity could be found with prednisolone (9.69\%), cortison (1.85\%) and other steroids (>1\%) according to the 
manufacturer. Analytic sensitivity is located at $1.4 \mathrm{ng} / \mathrm{ml}$. The supplied standard curve was adjusted to a lower measurement range of $0.125 \mathrm{ng} / \mathrm{ml}$ by diluting it with buffer. Intra-assay coefficient of variation was $9.0 \%$.

\section{Statistical analysis}

Statistical analyses were performed with open-source packages of the R-project for Statistical Computing, which is accessible throughout the Comprehensive $\mathrm{R}$ Archive Network (R Core Team (2013). R: A language and environment for statistical computing. R Foundation for Statistical Computing, Vienna, Austria. URL http://www.R-project.org/).
The possible differences between the two sexes were investigated using a student-ttest. Pearson correlation was performed to evaluate relationships between cortisol concentrations in different matrices tested.

\section{Results}

\section{Clinical examination}

The male seals displayed a weight average of $67 \pm 24.1$ kilograms with a mean length of $158 \pm 18.7 \mathrm{~cm}$. The weight value for the female seals was $54.5 \pm 8.5$ kilograms on average, measuring of length displayed 145 $\pm 7.5 \mathrm{~cm}$ in females. Two harbor seals (1 male and 1 female) were defined to be juvenile. The other 15 animals were classified as mature. Corresponding data is shown in table 1.

Table 1: General data of harbor seals examined during health monitoring program in spring 2013

\begin{tabular}{|c|c|c|c|c|c|c|}
\hline $\begin{array}{l}\text { animal } \\
\text { number }\end{array}$ & species & $\begin{array}{c}\text { date of } \\
\text { examination }\end{array}$ & $\begin{array}{c}\text { age } \\
\text { (estimated) }\end{array}$ & gender & $\begin{array}{l}\text { total lenght } \\
(\mathrm{cm})\end{array}$ & weight (kg) \\
\hline 1 & Phoca vitulina & April 2013 & mature & male & 175 & 105 \\
\hline 2 & Phoca vitulina & April 2013 & mature & male & 170 & 94.5 \\
\hline 3 & Phoca vitulina & April 2013 & mature & male & 175 & 98.6 \\
\hline 4 & Phoca vitulina & April 2013 & mature & male & 186 & 86 \\
\hline 5 & Phoca vitulina & April 2013 & mature & male & 163 & 67.5 \\
\hline 6 & Phoca vitulina & April 2013 & mature & male & 178 & 74.3 \\
\hline 7 & Phoca vitulina & April 2013 & mature & male & 150 & 55.5 \\
\hline 8 & Phoca vitulina & April 2013 & mature & male & 122 & 36.7 \\
\hline 9 & Phoca vitulina & April 2013 & mature & male & 175 & 84 \\
\hline 10 & Phoca vitulina & April 2013 & mature & male & 142 & 46.7 \\
\hline 11 & Phoca vitulina & April 2013 & mature & male & 144 & 39.3 \\
\hline 12 & Phoca vitulina & April 2013 & mature & male & 145 & 40.3 \\
\hline \multirow[t]{3}{*}{13} & Phoca vitulina & April 2013 & immature & male & 135 & 42.5 \\
\hline & & \multicolumn{3}{|c|}{ mean } & 159 & 67.8 \\
\hline & & \multicolumn{3}{|c|}{ standard deviation } & 18.7 & 24.1 \\
\hline 14 & Phoca vitulina & April 2013 & mature & female & 143 & 57 \\
\hline 15 & Phoca vitulina & April 2013 & mature & female & 155 & 61.5 \\
\hline 16 & Phoca vitulina & April 2013 & mature & female & 146 & 56.8 \\
\hline \multirow[t]{3}{*}{17} & Phoca vitulina & April 2013 & immature & female & 137 & 42.1 \\
\hline & & \multicolumn{3}{|c|}{ mean } & 145 & 54.4 \\
\hline & & \multicolumn{3}{|c|}{ standard deviation } & 7.5 & 8.5 \\
\hline
\end{tabular}

Neele Hendrika Gundlach, Marion Piechotta and Ursula Siebert (2016), International Journal of Veterinary Medicine: Research \& Reports, DOI: 10.5171/2016.967043 


\section{Statistical analysis}

Significant gender distinctions could not be found.

But for lachrymal fluid and serum cortisol $\left(\mathrm{R}^{2}=0.82, \mathrm{p}<0.01\right)$ a significant correlation could be detected. Saliva and lachrymal fluid comparison also showed a significant correlation $\left(\mathrm{R}^{2}=0.68, \mathrm{p}<0.05\right)$. Additionally, this could be found between serum and saliva cortisol concentrations $\left(\mathrm{R}^{2}=0.60\right.$, $\mathrm{p}<0.05$ ).

\section{Laboratory analysis}

Blood counts and clinical chemistry
As it is shown in table 2, in 16 animals the numbers of leucocytes were within the normal range (mean $11.1 \pm 3.9 \mathrm{G} / \mathrm{l}$ ). One adult female showed several skin wounds and an ulcer on the left cornea. The skin lacerations were located on the left lateral flank as well as ventral close to the fluke. Concerning the blood sample of this seal, one could also find an increased number of leucocytes as well as a slight rise in total protein (mean $88 \pm 6.5 \mathrm{~g} / \mathrm{l}$ ). The mean hematocrit was $56 \%( \pm 2.2 \%)$ on average in male and $54.5 \%( \pm 10.2 \%)$ in female. A minor decrease in hematocrit as well as erythrocyte and thrombocyte numbers related to reference values could also be detected in the injured female.

Table 2: Blood status of 17 harbor seals examined during health monitoring program in April 2013

\begin{tabular}{|c|c|c|c|c|c|c|c|c|c|c|c|c|c|c|}
\hline $\begin{array}{l}\text { animal } \\
\text { number }\end{array}$ & $\begin{array}{c}\text { age } \\
\text { (estimated) }\end{array}$ & gender & $\begin{array}{r}\text { leucocytes } \\
(10 \times-9 / 1)\end{array}$ & $\begin{array}{l}\text { erythrocytes } \\
\text { ( } 10 \times-12 / I)\end{array}$ & $\begin{array}{c}\text { hematocrit } \\
\text { (\%) }\end{array}$ & $\begin{array}{c}\text { haemoglobin } \\
(\mathrm{g} / \mathrm{dl})\end{array}$ & $\begin{array}{l}\text { thrombocytes } \\
\text { (10 x -9/I) }\end{array}$ & $\begin{array}{c}\text { total protein } \\
(\mathrm{g} / \mathrm{dl})\end{array}$ & $\begin{array}{l}\text { albumin } \\
(\mathrm{g} / \mathrm{l})\end{array}$ & $\begin{array}{c}\text { globuline } \\
(\mathrm{g} / \mathrm{l})\end{array}$ & $\begin{array}{c}\text { alkaline } \\
\text { phosphatase } \\
\text { (U/I) }\end{array}$ & $\begin{array}{c}\text { alanine amino- } \\
\text { transferase } \\
(\mathrm{U} / \mathrm{I})\end{array}$ & $\begin{array}{c}\text { urea } \\
\text { (mg/dl) }\end{array}$ & $\begin{array}{c}\text { creatinine } \\
\text { (mg/dl) }\end{array}$ \\
\hline 1 & mature & male & 9.2 & 4.6 & 53.7 & 19.6 & 393 & 96 & 42 & 5.4 & 17 & 54 & 52 & 1.1 \\
\hline 2 & mature & male & 11.1 & 5.12 & 60.7 & 22 & 313 & 90 & 39 & 5 & 27 & 63 & 28 & 1.3 \\
\hline 3 & mature & male & 13.2 & 5.06 & 59.2 & 21 & 333 & 92 & 41 & 5.1 & 22 & 57 & 36 & 1.3 \\
\hline 4 & mature & male & 11.5 & 4.57 & 54.3 & 20.3 & 386 & 85 & 41 & 4.4 & 27 & 36 & 34 & 1 \\
\hline 5 & mature & male & 10.4 & 4.73 & 56.3 & 20.8 & 391 & 87 & 40 & 4.7 & 30 & 43 & 49 & 1.2 \\
\hline 6 & mature & male & 8.3 & 4.97 & 56.2 & 20.3 & 339 & 81 & 43 & 3.8 & 31 & 42 & 33 & 0.5 \\
\hline 7 & mature & male & 9.1 & 4.6 & 53.2 & 20.6 & 304 & 83 & 43 & 4 & 23 & 46 & 36 & 0.9 \\
\hline 8 & mature & male & 9.9 & 4.23 & 50.2 & 19.2 & 407 & 79 & 41 & 3.8 & 33 & 46 & 44 & 0.9 \\
\hline 9 & mature & male & 11.2 & 4.79 & 56.5 & 20 & 81 & 102 & 39 & 6.3 & 47 & 219 & 50 & 0.7 \\
\hline 10 & mature & male & 10.4 & 4.87 & 56.8 & 20.2 & 306 & 85 & 43 & 4.2 & 20 & 41 & 55 & 0.5 \\
\hline 11 & mature & male & 10.3 & 4.59 & 53.7 & 20.4 & 370 & 93 & 38 & 5.6 & 33 & 40 & 39 & 0.8 \\
\hline 12 & mature & male & 11.3 & 5.59 & 54.7 & 19.9 & 339 & 87 & 38 & 4.9 & 39 & 111 & 38 & 0.7 \\
\hline 13 & immature & male & 9.2 & 4.81 & 56.9 & 20.1 & 473 & 87 & 38 & 5 & 33 & 45 & 33 & 0.9 \\
\hline 14 & mature & female & 7.7 & 4.97 & 59.1 & 21.1 & 354 & 80 & 40 & 4.1 & 35 & 62 & 55 & 0.9 \\
\hline 15 & mature & female & 24.9 & 3.63 & 39.5 & 14 & 160 & 98 & 25 & 7.4 & 16 & 69 & 42 & 0.5 \\
\hline 16 & mature & female & 9 & 5.14 & 62.1 & 20.7 & 339 & 83 & 40 & 4.3 & 38 & 58 & 38 & 0.7 \\
\hline 17 & immature & female & 9.1 & 4.85 & 57.2 & 23 & 390 & 90 & 38 & 5.2 & 29 & 59 & 47 & 0.7 \\
\hline
\end{tabular}

\section{Cortisol concentrations}

Regarding all samples, cortisol could be detected in lachrymal fluid, saliva and blood.

\section{Serum}

Serum cortisol was $203 \pm 60 \mu \mathrm{g} / \mathrm{dl}$ in male and $299 \pm 178 \mu \mathrm{g} / \mathrm{dl}$ in female (mean $\pm \mathrm{SD}$ ). Compared to all tested animals, seven harbor seals (four males, three females) depicted an elevated cortisol values in blood without any abnormality in hematology. The maximum level could be found in the female seal with skin and ocular injuries.

\section{Saliva and lachrymal fluid}

The observations in serum cortisol concentrations also coincide with the results of cortisol in tear (male $0.28 \pm 0.15$ $\mu \mathrm{g} / \mathrm{dl}$, female $0.42 \pm 0.19 \mu \mathrm{g} / \mathrm{dl}$ ) and saliva (male $0.768 \pm 0.563 \mu \mathrm{g} / \mathrm{dl}$, female $1.232 \pm$ $0.539 \mu \mathrm{g} / \mathrm{dl})$. 
Table 3: Cortisol concentrations in blood, tears and saliva of 17 harbor seals examined during health monitoring program in April 2013

\begin{tabular}{|c|c|c|c|c|c|}
\hline \multirow[t]{2}{*}{$\begin{array}{l}\text { animal } \\
\text { number }\end{array}$} & \multirow[t]{2}{*}{$\begin{array}{c}\text { age } \\
\text { (estimated) }\end{array}$} & \multirow[t]{2}{*}{ gender } & \multicolumn{3}{|c|}{$\begin{array}{l}\text { cortisol ( } \mu \mathrm{g} / \mathrm{dl} \text { ) } \\
\text { lachrymal }\end{array}$} \\
\hline & & & serum & fluid & saliva \\
\hline 1 & mature & male & 124 & 0.18 & 0.268 \\
\hline 2 & mature & male & 122 & 0.14 & 0.398 \\
\hline 3 & mature & male & 193 & 0.25 & 0.26 \\
\hline 4 & mature & male & 185 & 0.17 & 1.046 \\
\hline 5 & mature & male & 153 & 0.09 & 0.312 \\
\hline 6 & mature & male & 238 & 0.56 & 0.716 \\
\hline 7 & mature & male & 282 & 0.32 & 0.624 \\
\hline 8 & mature & male & 272 & 0.48 & 2.267 \\
\hline 9 & mature & male & 323 & 0.50 & 1.031 \\
\hline 10 & mature & male & 178 & 0.17 & 1.117 \\
\hline 11 & mature & male & 193 & 0.18 & 0.358 \\
\hline 12 & mature & male & 179 & 0.32 & 1.14 \\
\hline \multirow[t]{3}{*}{13} & immature & male & 197 & 0.23 & 0.441 \\
\hline & & mean & 203 & 0.28 & 0.768 \\
\hline & & standard deviation & 60 & 0.15 & 0.563 \\
\hline 14 & mature & female & 203 & 0.36 & 1.282 \\
\hline 15 & mature & female & 564 & 0.67 & 1.829 \\
\hline 16 & mature & female & 242 & 0.44 & 1.296 \\
\hline \multirow[t]{3}{*}{17} & immature & female & 188 & 0.23 & 0.52 \\
\hline & & mean & 299 & 0.42 & 1.232 \\
\hline & & standard deviation & 178 & 0.19 & 0.539 \\
\hline
\end{tabular}

Correlation of cortisol concentration in serum, saliva and lachrymal fluid

Figure 1-2 show the evaluation of regression analysis between serum cortisol and "free" cortisol concentrations in lachrymal fluid with $\mathrm{R}^{2}=0.82(\mathrm{p}<0.01)$ for linear correlation and $\mathrm{R}^{2}=0.67(\mathrm{p}<0.01)$ for exponential regression.

Comparing the concentrations of unbound cortisol in saliva and tears, the following correlation with $\mathrm{R}^{2}=0.68(\mathrm{p}<0.05)$ could be estimated. Regression analysis for saliva and serum cortisol concentration $\left(\mathrm{R}^{2}=\right.$ $0.60, \mathrm{p}<0.05$ ) is shown in figure 4 .

Figure 1-2: Linear and exponential regression of lachrymal fluid and serum cortisol $(\mu \mathrm{g} / \mathrm{dl})$ in 17 harbor seals
Figure 3-4: Linear regression analysis of cortisol concentration $(\mu \mathrm{g} / \mathrm{dl})$ in lachrymal fluid, serum and saliva in 17 harbor seals

\section{Discussion}

Cortisol, released by the adrenal gland, is referred to as one of the main stress hormones to evaluate a stress response. Serious restraint and mild pain associated with venipuncture as the reference technique, however, is already sufficient for an increase of the stress hormone levels, especially for wild animals (Mormède et al., 2007, Cook et al., 2000). There have been several attempts to avoid or ease this influence by using indwelling catheters or habituation effects to serial sampling (Hopster et al., 1999) as well as training for voluntary husbandry behaviors, for example in harbor porpoises (Desportes et al., 2007). Nonetheless, a rapid sampling method of an appropriate material is 
needed for stress assessment in nondomestic animals.

Besides the mentioned difficulties of interpretation of blood cortisol concentrations, saliva, as an ultra-filtrate of blood, has the disadvantage that the matrix can be influenced by a possible contamination of food remains or blood. In addition, sampling from the oral cavity depends on the compliance of the animal in order to limit the risk for the examiner (Groeschl 2008, Sheriff et al., 2011). Lachrymal fluid was used in human research (Banbury 2009) and also evaluated as an alternative in a study of the effects of a mild stress challenge in dairy cattle (Khraim 2011). In this study, the author found evidence for painless sampling of tear fluid during lateral recumbency, bearing less risk of influencing cortisol concentration due to mental stress or stress related to pain (Khraim 2011). This discovery was also reflected in a significant correlation between serum and tear cortisol concentrations.

Certainly, the examination of wild animals, in comparison to farm animals, includes several difficulties. Aside from the lack of information of wild animals and its environment before and after temporal capture, missing experience of handling and trapping may exacerbate examination, sampling and the analysis (Sheriff et al., 2011). Hence, there is a need to confine possible pain- or stressful restraints and examination to a minimum. Consequently, we tried to find other methods and material to reduce the amount of invasive collected samples. So, in the course of the first inspection, lachrymal fluid was sampled from the conjunctival sack by softtissue swaps. Additionally, serum and saliva were sampled to compare the obtained data.

Cortisol was detected in all sampling materials (lachrymal fluid, saliva, blood) investigated in the present study.

The results of this study showed a clear increase in serum cortisol concentration in seven harbor seals (four males, three female). As earlier stated, trapping and fixation for investigative purpose may already cause an increase of cortisol concentration without receiving further information about possible stress condition before handling. This is also described in Eskesen's (2009) stress research study investigating forty-five harbor porpoises trapped in pound nets.

Still, possible interactions between glucocorticoids and the immune system have to be taken into account as the health status may also influence the level of cortisol (Fonfara et al., 2007, Desportes et al., 2007, Beineke et al., 2010). So an additional blood cell count and clinical chemistry were performed for further clarification. Here, the injured female seal showed the highest cortisol concentration combined with a slight rise in total protein (mean $88 \pm 6.5 \mathrm{~g} / \mathrm{l}$ ), indicating a possible infection. The decrease in hematocrit concerning this female as well as erythrocyte and thrombocyte numbers related to reference values may also be due to the skin wounds and a possible blood loss. This shows that illness and pain, combined with an activation of the immune and stress system, can cause an increase of cortisol via different pathways and interactions. Hence in this case, a clear distinction whether this gain in cortisol concentration results from the change in situation or the health status is not possible. Another likely explanation is that the cortisol concentration of this female seal already reached its maximum due to disease as a kind of 'ceiling effect' (Mellor et al., 2000) and so a further increase caused by trapping and handling could not be displayed.

Aside from serum cortisol, cortisol was also detected in saliva in the present survey, although regression analysis displayed only a moderate correlation between serum and saliva cortisol values. Determination of cortisol in saliva and also lachrymal fluid is limited to the free form of cortisol as saliva and tears are devoid of binding proteins. So, compared to plasma, saliva assays have to cope with a reduced sensitivity and specifity (Mormède et al., 2007) due to a lower cortisol concentration in saliva 
(Banbury 2009). Furthermore, a time lag between blood and subsequent changes in saliva values is also discussed in cortisol measurement in sheep and humans (Cook 2002). Perez et al., (2004) even described a possible variability between individuals within the same breed and age group in cattle.

Tear fluid reflected a good alternative to blood investigation in this study. In humans it could also be discovered that cortisol measurable in tear fluid had a proper correlation to blood cortisol (Banbury 2009). The regression analysis in our study displayed a reliable correlation between lachrymal fluid and serum cortisol results in harbor seals. Therefore, we concluded that changes of the hypothalamic-pituitaryadrenal (HPA) axis are also reflected by stress hormone changes in lachrymal fluid. Proof for this simultaneous increase of cortisol in different body fluid can also be found in the study of the effects of dexamethasone on the HPA - axis in cattle (Khraim 2011). Here, a suppression of HPA with this synthetic glucocorticoid led to a corresponding decrease of cortisol values in serum as well as in lachrymal fluid.

As the concentrations in lachrymal fluid of harbor seals were much less than in humans, the measuring range of the assay had to be adapted. Determination of low cortisol level implies certain difficulties which may result in an underestimated correlation between serum and lachrymal fluid results. This could also be seen in the study in dairy cattle of Khraim (2011). He deduced that taking samples from the conjunctival sack was less invasive as there was no increase in heart or respiration rate during this period. Furthermore, rapid performance of tear sampling reduces exogenous stimulation of HPA - axis, as it can be seen in catheterized animals (Cook et al., 2000), and so diminishes stress effects due to collection procedure. Consequently, lachrymal fluid sampling may function as a reliable and quick method for measuring cortisol concentration in wild harbour seals, too.

\section{Conclusion}

The examined group of free-ranging harbor seals consisted of animals in similar age and weight states, comparable to each other. Only one female showed obvious signs of illness. Cortisol could be detected in all investigated materials, with a significant correlation between cortisol in serum and tears. As far as the author's know this is the first time such an approach was carried out in the investigation of stress reactions in wild harbor seals. Thus, lachrymal fluid may be a potential noninvasive alternative for stress the assessment of stress in harbor seals and this technique could be useful to reduce the fixation of animals for examination purposes. Nonetheless, a higher sampling number might be needed as well as a randomized study design in order to validate each method as less or even noninvasive.

\section{Acknowledgements}

The study was supported by the authorities for coastal protection, national parks and marine protection, Wadden Sea national park administration Toenning of Schleswig-Holstein, Germany. Thanks to the volunteers and staff members helping with the health monitoring program as well as the Endocrinology Laboratory.

\section{References}

1. Atkinson, S. (1997) "Reproductive biology of seals". Reviews of Reproduction, 2(3), 175-194.

2. Banbury, L. K. (2009) "Stress biomarkers in the tear film." PhD thesis, Southern Cross University, Lismore, NSW.

3. Beineke, A., Siebert, U., Wohlsein, P. and Baumgaertner, W. (2010) "Immunology of whales and dolphins." Veterinary Immunology and Immunopathology, 133(2), 81-94.

4. Cook, C. J., Mellor, D. J., Harris, P. J., Ingram, J. R. and Matthews, L. R. (2000)

"Hands-on and hands-off measurement of

Neele Hendrika Gundlach, Marion Piechotta and Ursula Siebert (2016), International Journal of Veterinary Medicine: Research \& Reports, DOI: 10.5171/2016.967043 
stress." The Biology of Animal Stress. CABI Publishing, 123-46.

5. Cook, C. J. (2002) "Rapid noninvasive measurement of hormones in transdermal exudate and saliva." Physiology \& Behavior, 75(1), 169-181.

6. Chrousos, G. P. (2009) "Stress and disorders of the stress system." Nature Reviews Endocrinology, 5(7), 374-381.

7. Dierauf, L. A., and Gulland, F. M. (2010) CRC handbook of marine mammal medicine: health, disease, and rehabilitation. CRC press.

8. Desportes, G., Buholzer, L., AndersonHansen, K., Blanchet, M., Acquarone, M., Shephard, G., Brando, S. , Vossen, A. and Siebert, U. (2007) "Decrease stress; train your animals: The effect of handling methods on cortisol levels in harbour porpoises (Phocoena phocoena) under human care." Aquatic Mammals, 33(3), 286.

9. Eskesen I.G., Geertsen B.M., Teilmann J., Desportes G., Riget F., Dietz R., Larsen F. and Siebert U. (2009) "Stress level in wild harbour porpoises (Phocoena phocoena) during satellite tagging measured by respiration, heart rate and cortisol." Journal of Biological Society of the United Kingdom, 89(5), 885-892.

10.Evans, G. W. (1984) "Environmental stress." CUP Archive, Cambridge, United Kingdom

11.Fair, P. A., and Becker, P.R. (2000) "Review of stress in marine mammals." Journal of Aquatic Ecosystem Stress and Recovery, 7.4, 335-354

12.Fonfara, S., Siebert, U., Prange, A., and Colijn, F. (2007) "The impact of stress on cytokine and haptoglobin mRNA expression in blood samples from harbour porpoises (Phocoena phocoena)." Journal of the Marine Biological Association of the United Kingdom, 87(1), 305-311.

13.Groeschl, M. (2008) " Current status of salivary hormone analysis." Clinical Chemistry, 54(11), 1759-1769.
14.Haerkoenen, T., Dietz, R., Reijnders, P., Teilmann, J., Harding, K., Hall, A., Brasseur, S., Siebert, U., Goodman S.J., Dau Rasmussen, T. and Thompson, P. (2006) "The 1988 and 2002 phocine distemper virus epidemics in European harbour seals." Diseases of aquatic organisms, 68(2), 115-130.

15.Hasselmeier, I., Fonfara, S., Driver, J., and Siebert, U. (2008) "Differential hematology profiles of free-ranging, rehabilitated, and captive harbor seals (Phoca vitulina) of the German North Sea". Aquatic Mammals, 34(2), 149-156.

16. Hopster, H., Van Der Werf, J. T., Erkens, J. H. and Blokhuis, H. J. (1999) "Effects of repeated jugular puncture on plasma cortisol concentrations in loose-housed dairy cows." Journal of Animal Science, 77(3), 708-714.

17.Khraim, N. M. (2011) "Effects of Dexamethasone and Training on the Hypothalamic Pituitary Adrenal Response on Mild Stress Challenge in Dairy Cows." PhD Thesis, University of Veterinary Medicine Hannover, Germany

18.Koolhaas, J. M., Bartolomucci, A., Buwalda, B., De Boer, S. F., Flügge, G., Korte, S. M., Meerlo, P., R. Murisong, R., Olivier, B., Palanzak, P., Richter-Levine, G., Sgoifok, A., Steimerj, T., Stiedl, O., van Dijkh, G., Wöhrd, M. and Fuchs, E. (2011) "Stress revisited: a critical evaluation of the stress concept." Neuroscience \& Biobehavioral Reviews, 35(5), 1291-1301.

19.Mellor, D. J., Cook, C. J., and Stafford, K. J. (2000) "Quantifying some responses to pain as a stressor." The biology of animal stress: basic principles and implications for animal welfare, CABI Publishing, Wallingford, UK, 171-198.

20.Moestl, E., and Palme, R. (2002. "Hormones as indicators of stress." Domestic Animal Endocrinology, 23(1), 6774.

21.Mormède, P., Andanson, S., Aupérin, B., Beerda, B., Guémené, D., Malmkvist, J., Manteca, X., Manteuffel G., Prunet P., van 
Reenen, C.G., Richard S. and Veissier, I. (2007) "Exploration of the hypothalamicpituitary-adrenal function as a tool to evaluate animal welfare." Physiology \& Behavior, 92(3), 317-339.

22.Mueller, S., Lehnert, K., Seibel, H., Driver, J., Ronnenberg, K., Teilmann, J., van Elk, C. Kristensen, J. Everaarts, E. and Siebert, U. (2013) "Evaluation of immune and stress status in harbour porpoises (Phocoena phocoena): can hormones and mRNA expression levels serve as indicators to assess stress?" BMC veterinary research, 9(1), 145.

23.0ki, C. and Atkinson, S. (2004) "Diurnal patterns of cortisol and thyroid hormones in the Harbor seal (Phoca vitulina) during summer and winter seasons." General and Comparative Endocrinology, 136(2), 289297.

24.Chacón Pérez, G., García-Belenguer Laita, S., Illera del Portal, J. C. and Palacio Liesa, J. (2004). "Validation of an EIA [enzyme immunoassay] technique for the determination of salivary cortisol in cattle." Spanish Journal of Agricultural Research, 2(1), 45-51.

25.R Development Core Team 2011 " $R$ : $A$ Language and Environment for Statistical Computing" (Vienna: R Foundation for Statistical Computing) (www.Rproject.org/)

26.Romero, M. L. and Butler, L. K. (2007) "Endocrinology of stress." International Journal of Comparative Psychology, 20(2).
27.Selye, H. (1950) "Stress, the Physiology and Pathology of Exposure to Stress." Acta Medica

28.Selye, H. (1955) "Stress and disease." The Laryngoscope, 65(7), 500-514.

29.Sheriff, M. J., Dantzer, B., Delehanty, B., Palme, R. and Boonstra, R. (2011). "Measuring stress in wildlife: techniques for quantifying glucocorticoids." Oecologia, 166(4), 869-887.

30.Siebert U., Pozniak B., Anderson Hansen K., Nordstrom G., Teilmann J., van Elk N., Vossen A. and Dietz R. (2012) "Investigations of thyroid and stress hormones in free-ranging and captive harbor porpoises (Phocoena phocoena): a pilot study." Aquatic mammals 37 (4), 443453.

31.Swietlik, M. (2011) „Grundbegriffe der Umweltpsychologie: Stressoren (Klima, Hitze, Kälte, Gerüche, Schadstoffe).“ GRIN Verlag, Munich, Germany.

32.Trites, A. W., and Pauly, D. (1998) "Estimating mean body masses of marine mammals from maximum body lengths." Canadian Journal of Zoology, 76(5), 886896.

33.Wright, A. J., Deak, T. and Parsons, E. C. M. (2009). "Concerns related to chronic stress in marine mammals." Inter Whaling Commission, 1-7.

Neele Hendrika Gundlach, Marion Piechotta and Ursula Siebert (2016), International Journal of Veterinary Medicine: Research \& Reports, DOI: 10.5171/2016.967043 